\title{
Reducing the adverse impact of injection drug use in Canada
}

\author{
Kevin B Laupland MD MSc FRCPC ${ }^{1}$, John M Embil MD FRCPC ${ }^{2}$
}

Tjection of illicit drugs is a major health problem worldwide. There are currently an estimated 100,000 injection drug users in Canada (1). Infectious complications of injection drug use (IDU) include, but are not limited to, injection-related skin and soft tissue infection and abscesses, bloodstream infection and endocarditis, and infection by transmission of blood borne pathogens, such as HIV, hepatitis viruses and syphilis (2-4). In addition, IDU is associated with a general increased risk for infection such as with pneumonia and for acquisition of antimicrobial resistant organisms, most notably methicillin-resistant Staphylococcus aureus (5). Indirectly, IDU is associated with other behaviours and social circumstances that lead to further infectious disease risk and general adverse health consequences $(6,7)$.

Illicit drug use policy in Canada for the past century has been centred around criminalization and punishment of users and traffickers (8). However, there is increasing recognition of the outright failure of this approach. Illicit drug use remains common, and the market for illegal drug profits drives most of the organized crime activity in this country (9). Fueled in part by the apparent futility of criminalization and punishment approaches so far, there has been increasing recognition of the value of 'harm reduction' strategies. Harm reduction generally refers to programs, policies or interventions that aim to reduce or minimize the adverse consequences associated with drug use (10). Initial approaches surrounding harm reduction in the 1980s involving increased access to supplies of sterile needles and safe disposal or exchange led to reductions in infectious complications (11).

In the 1990s, rates of HIV infection and deaths due to illegal drug use rose significantly in British Columbia, particularly in the downtown east side of Vancouver related to heroine abuse (12). Harm reduction was recognized as a necessary and major component of an intervention strategy and received growing community and governmental support. Insite (www.communityinsite.ca), a supervised injection facility, was subsequently opened as a pilot project following an exemption from the Controlled Drugs and Substances Act granted by the Government of Canada. Insite is located in the downtown east side of Vancouver (13). It provides IDUs with a supervised safe setting where sterile needles and syringes are supplied for the users to inject their own drugs. Health care personnel, including registered nurses, monitor patients and are available for management of adverse events. Hundreds of thousands of injections occur annually at this location.

So what has been the impact of Insite? Use of the facility has been demonstrated to reduce needle sharing among its users (14). One analysis estimated that two to 12 deaths due to overdose have been averted annually by the facility (15). In another mathematical modelling study, it was estimated that Insite prevents an average of 35 cases of HIV infection and three deaths per year (16). In addition, these investigators found that after program costs were taken into account, Insite provided an estimated net societal benefit of $\$ 6,000,000$ per year. Although other investigators have modelled infection rates and associated costs with varying results, the common conclusion is that infections and societal costs are reduced $(17,18)$. It is noteworthy that Insite may also improve public order through less litter and disturbance resulting from public injection, increase the odds of users accessing addictions treatment and lead to earlier referral for treatment of infectious complications $(19,20)$.
Despite the fact that Insite has saved lives, prevented infections, promoted and facilitated addictions treatment, and saved public dollars, it has remained a source of controversy. Insite's ability to remain open has been uncertain and is continually at risk with governmental challenges of the legality to continue operation (21). Opposition largely relates to objections to the 'permissive' use of controlled substances. In addition, a number of potential moral, ethical and political issues have been raised, including the use of tax payer funds to support this ultimately illegal activity, and unfounded concerns that such a facility may be condoning or legitimizing IDU. However, it is recognized that additional lives would be saved and infections prevented by the addition of supervised injecting facilities in many other Canadian cities (22).

So what are our roles as members of the infectious disease and medical microbiology community in Canada? First, we believe that we must put aside any personal ethical and moral opposition that we may have against supervised injection facilities and focus on the fact that they can prevent infections, save lives and lessen the adverse societal impact of illicit drug use. Second, we should explicitly state our support to the public and political leaders not only for these centres, but for other novel initiatives that aim to reduce the adverse effects of illicit drug use and its associated infectious consequences. Finally, we must express our admiration, praise and gratitude to the individuals, communities and organizations in Canada that have championed the development of Insite and support further harm reduction initiatives for IDUs.

\section{REFERENCES}

1. Injection Drug Users Overview-Canadian Centre on Substance Abuse, $2012<$ www.ccsa.ca/Eng/Topics/Populations/IDU/Pages/ InjectionDrugUsersOverview.aspx > (Accessed June 19, 2012).

2. Binswanger IA, Takahashi TA, Bradley K, Dellit TH, Benton KL, Merrill JO. Drug users seeking emergency care for soft tissue infection at high risk for subsequent hospitalization and death. J Stud Alcohol Drugs 2008;69:924-32.

3. Gerlich M, Gschwend P, Uchtenhagen A, Kramer A, Rehm J. Prevalence of hepatitis and HIV infections and vaccination rates in patients entering the heroin-assisted treatment in Switzerland between 1994 and 2002. Eur J Epidemiol 2006;21:545-9.

4. Palepu A, Tyndall MW, Leon H, et al. Hospital utilization and costs in a cohort of injection drug users. Can Med Assoc J 2001;165:415-20.

5. Gilbert M, MacDonald J, Gregson D, et al. Outbreak in Alberta of community-acquired (USA300) methicillin-resistant Staphylococcus aureus in people with a history of drug use, homelessness or incarceration. Can Med Assoc J 2006;175:149-54.

6. Shannon K, Kerr T, Marshall B, et al. Survival sex work involvement as a primary risk factor for hepatitis $\mathrm{C}$ virus acquisition in drug-using youths in a Canadian setting. Arch Pediatr Adolesc Med 2010;164:61-5.

7. Gilbert M, Macdonald J, Louie M, et al. Prevalence of USA300 colonization or infection and associated variables during an outbreak of community-associated methicillin-resistant Staphylococcus aureus in a marginalized urban population. Can J Infect Dis Med Microbiol 2007;18:357-62.

8. Riley D. Drugs and drug policy in Canada: A brief review \& commentary, $1998<$ www.cfdp.ca/sen1841.htm> (Accessed June 19, 2012).

${ }^{1}$ Departments of Medicine, Critical Care Medicine, Pathology and Laboratory Medicine, and Community Health Sciences, Peter Lougheed Centre and University of Calgary, Calgary, Alberta; ${ }^{2}$ Departments of Medicine, (Section of Infectious Diseases) and Medical Microbiology,

University of Manitoba, Winnipeg, Manitoba

Correspondence: Dr Kevin B Laupland, Peter Lougheed Centre, 3500-36th Street Northeast, Calgary, Alberta T1Y 6J4.

Telephone 403-943-5785, fax 403-291-1491, e-mail kevin.laupland@calgaryhealthregion.ca 
9. Criminal Intelligence, Royal Canadian Mounted Police. Report on the Illicit Drug Situation in Canada, 2009.

10. Beirness DJ, Jesseman R, Notarandrea R, Perron M. Harm reduction. What's in a name?: Canadian Centre on Subtance Abuse, 2008. < www.ccsa.ca/Eng/Topics/HarmReduction/Pages/ default.aspx> (Accessed June 19, 2012).

11. Tomolillo CM, Crothers LJ, Aberson CL. The damage done: A study of injection drug use, injection related abscesses and needle exchange regulation. Subst Use Misuse 2007;42:1603-11.

12. Fafard P. Public health understandings of policy and power: Lessons from INSITE. J Urban Health 2012 May 2 (Epub ahead of print).

13. Kerr T, Oleson M, Tyndall MW, Montaner J, Wood E. A description of a peer-run supervised injection site for injection drug users. J Urban Health 2005;82:267-75.

14. Kerr T, Tyndall M, Li K, Montaner J, Wood E. Safer injection facility use and syringe sharing in injection drug users. Lancet 2005;366:316-8.

15. Milloy MJ, Kerr T, Tyndall M, Montaner J, Wood E. Estimated drug overdose deaths averted by North America's first medicallysupervised safer injection facility. PLoS One 2008;3:e3351.

16. Andresen MA, Boyd N. A cost-benefit and cost-effectiveness analysis of Vancouver's supervised injection facility. Int J Drug Policy 2010;21:70-6.
17. Pinkerton SD. How many HIV infections are prevented by Vancouver Canada's supervised injection facility? Int J Drug Policy 2011;22:179-83.

18. Pinkerton SD. Is Vancouver Canada's supervised injection facility cost-saving? Addiction 2010;105:1429-36.

19. DeBeck K, Kerr T, Bird L, et al. Injection drug use cessation and use of North America's first medically supervised safer injecting facility. Drug Alcohol Depend 2011;113:172-6.

20. Lloyd-Smith E, Wood E, Zhang R, et al. Determinants of hospitalization for a cutaneous injection-related infection among injection drug users: A cohort study. BMC Public Health 2010;10:327.

21. Small D. An appeal to humanity: Legal victory in favour of North America's only supervised injection facility: Insite. Harm Reduct J 2010;7:23.

22. Bayoumi AM, Strike C, Jairam J, et al. Report of the Toronto and Ottawa Supervised Consumption Assessment Study, 2012. Toronto: St Michael's Hospital and the Dalla Lana School of Public Health, University of Toronto. 


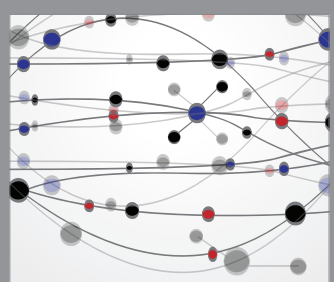

The Scientific World Journal
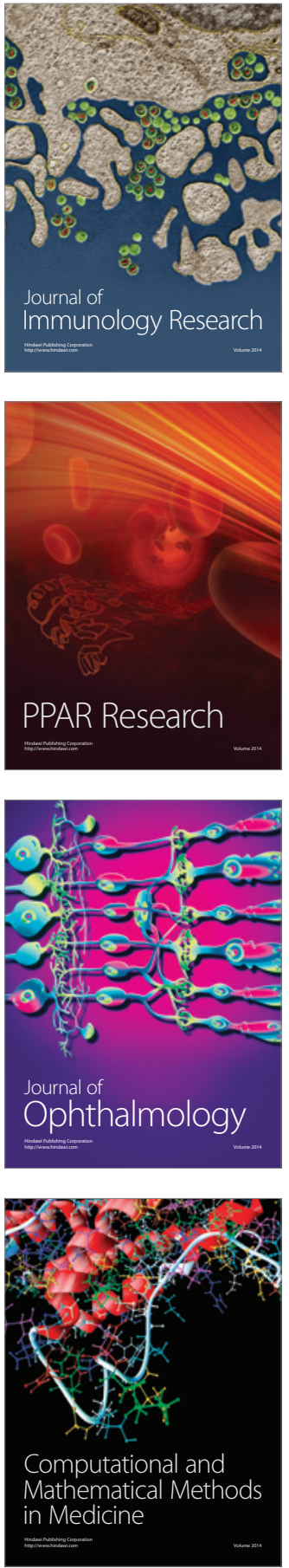

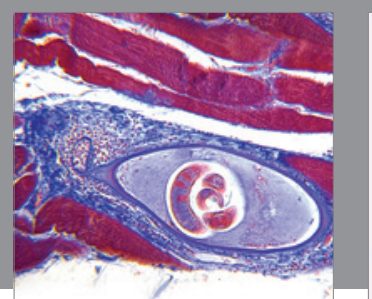

Gastroenterology Research and Practice

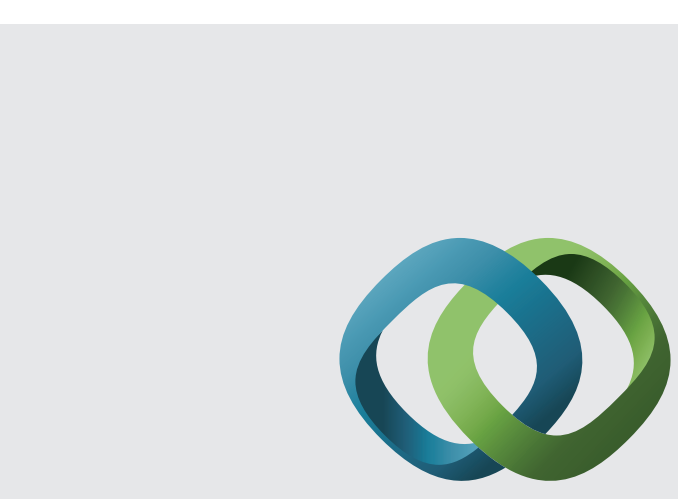

\section{Hindawi}

Submit your manuscripts at

http://www.hindawi.com
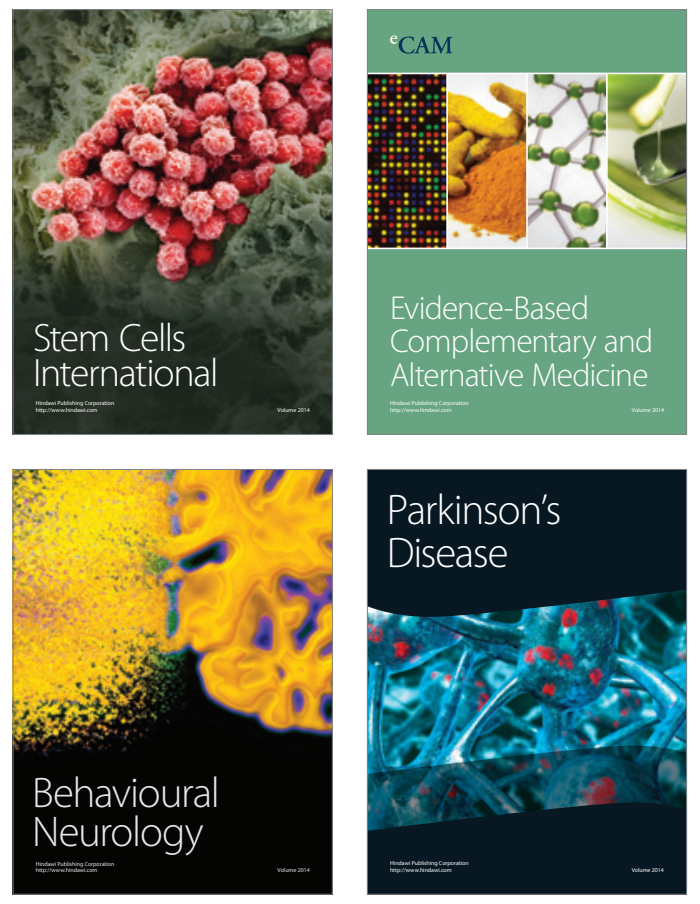
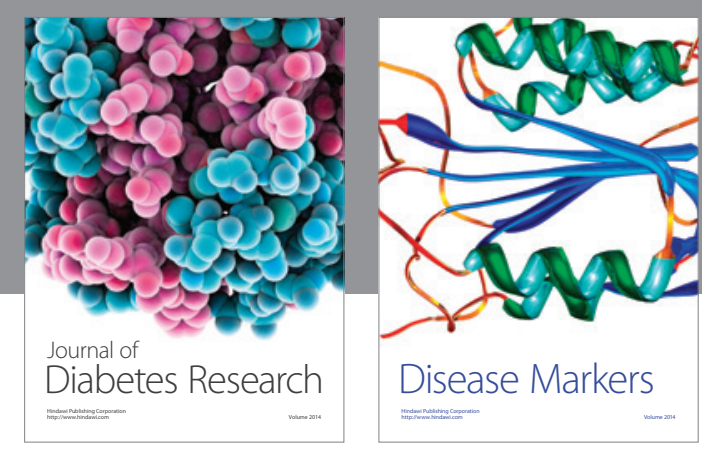

Disease Markers
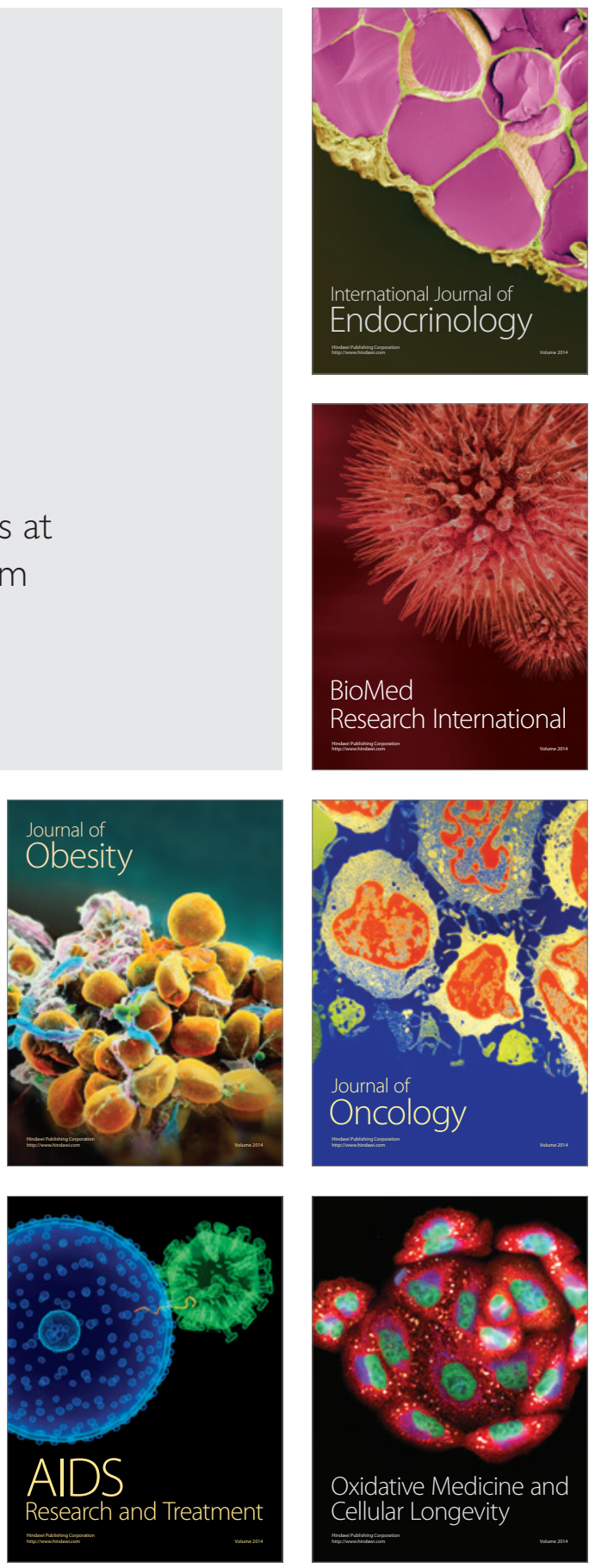